\title{
CONSUMER SEGMENTATION IN FOOD RETAILING IN CROATIA: A LATENT CLASS ANALYSIS
}

\section{SEGMENTACIJA POTROŠAČA U MALOPRODAJI HRANE U REPUBLICI HRVATSKOJ: ANALIZA LATENTNIH KLASA}

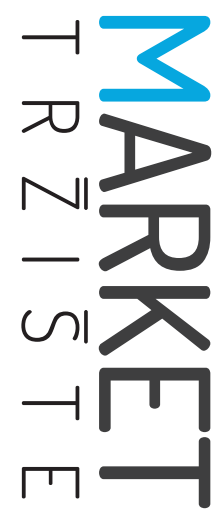

\author{
Market-Tržište \\ Vol. 32, Special Issue, 2020, pp. 9-29 \\ UDK 658.89:339.176(497.5) \\ DOl http://dx.doi.org/10.22598/mt/2020.32.spec-issue.9 \\ Original scientific paper
}

\begin{abstract}
Ivana Pavlića, Katija Vojvodićb, Barbara Puhc
a University of Dubrovnik, Department of Economics and Business, Lapadska obala 7, 20000 Dubrovnik, CROATIA, e-mail: ipavlic@unidu.hr

b University of Dubrovnik, Department of Economics and Business, Lapadska obala 7, 20000 Dubrovnik, CROATIA, e-mail: katija.vojvodic@unidu.hr

'University of Dubrovnik, Department of Economics and Business, Lapadska obala 7, 20000 Dubrovnik, CROATIA, e-mail: barbara.puh@unidu.hr
\end{abstract}

\begin{abstract}
Purpose - In order to anticipate satisfaction with a retail store and its offer, it is crucial to consider whether the store fulfils the expectations of different consumer fragments with regard to store attributes. The main goal of this paper was to identify different consumer segments in accordance with their level of satisfaction with various retail store elements and to define the profile of each segment.
\end{abstract}

Design/Methodology/Approach - An empirical study was conducted on 500 Croatian consumers, applying convenience sample through highly structured questionnaire. Using factor analysis, statements were divided into five meaningful dimensions (product assortment, price, store atmosphere, retail store quality and retail service quality). These factors were used as indicators for the latent class analysis.

Findings and implications - The findings have indicated an optimal solution of five consumer segments with different level of satisfaction. Each of the identified segments (convenience-oriented, disinterested, assortment-oriented, price-sensitive and grey consumers) is de-

\section{Sažetak}

Svrha - Kako bi se predvidjelo zadovoljstvo prodavaonicom i njezinom ponudom, ključno je razmotriti ispunjava li ona očekivanja različitih segmenata potrošača u pogledu njezinih obilježja. Glavna je svrha ovog rada bila identificirati različite segmente potrošača u skladu $s$ njihovom razinom zadovoljstva različitim elementima prodavaonice i definirati profil svakog od segmenata.

Metodološki pristup - Empirijsko istraživanje provedeno je na prigodnom uzorku od 500 hrvatskih potrošača putem visokostrukturiranog upitnika. Koristeći faktorsku analizu, izjave su podijeljene u pet dimenzija (asortiman proizvoda, cijena, ugođaj prodavaonice, kvaliteta prodavaonice i kvaliteta usluge prodavaonice). Ti su čimbenici korišteni kao indikatori za analizu latentnih klasa.

Rezultati i implikacije - Rezultati upućuju na optimalno rješenje pet segmenata potrošača s različitim stupnjem zadovoljstva. Svaki od identificiranih segmenata (potrošači orijentirani na pogodnosti, nezainteresirani potrošači, potrošači orijentirani na asortiman, cjenovno osjetljivi i stariji potrošači) opisan je prema sociodemografskim i bihevioralnim varijablama. Ovo istraživanje daje 
scribed in terms of socio-demographic and behavioural variables. This research provides insight into the factors that influence customer satisfaction. It also helps retail managers develop appropriate strategies to approach different consumer segments and improve their satisfaction.

Limitations - The research was undertaken in a single Croatian county, which can limit the generalisation of the findings. Another limitation refers to the use of factor results instead of the original list of items in the analysis of segments.

Originality - This study contributes to existing literature by providing useful insights into different consumer segments based on their level of satisfaction with retail store context in Croatian food retailing. Practical directions to target specific consumer segments more efficiently are proposed. As far as we know, no other studies have merged consumer segmentation and the latent class analysis in the context of the Croatian retail market.

Keywords - latent class analysis, consumers, food retail stores, segmentation, satisfaction uvid u čimbenike koji utječu na zadovoljstvo potrošača. Rad pomaže trgovcima razviti odgovarajuće strategije kako bi pristupili različitim segmentima potrošača i povećali njihovo zadovoljstvo.

Ograničenja - S obzirom na odabir uzorka, istraživanje je provedeno u jednoj hrvatskoj županiji, što može ograničavati generalizaciju nalaza. Drugo ograničenje odnosi se na korištenje faktorskih rezultata umjesto inicijalne liste elemenata u segmentacijskoj analizi.

Doprinos - Rad pridonosi postojećoj literaturi pružajući koristan uvid u različite segmente potrošača prema razini njihova zadovoljstva prodavaonicom u maloprodaji hrane u Hrvatskoj. Predloženi su praktični pravci za učinkovitije ciljanje određenih segmenata potrošača. Prema našim saznanjima, nijedna druga studija nije objedinila segmentaciju potrošača i analizu latentnih klasa u kontekstu hrvatskog maloprodajnog tržišta.

Ključne riječi - analiza latentnih klasa, potrošači, prodavaonice hrane, segmentacija, zadovoljstvo 


\section{INTRODUCTION}

Due to a competitive environment and its developments, the retail industry is going through a fast transformation. Nowadays, the differentiation of retail stores constitutes a crucial element in retailers' success. Diverse store attributes contribute to its differentiation from competitors. Therefore, customer satisfaction has become a topic of great interest to retailers that face the ever-changing needs of customers, demographics, diverse retail formats, as well as technological advancements. Consequently, retailers have made substantial investments in enhancing performance in those areas that contribute to increased customer satisfaction.

As observed by Willems, Brengman and van de Sanden (2017), in today's dynamic retail landscape, capturing shoppers' attention has become an extremely challenging task. In addition to product variety or quality, customers seek an experience, i.e. a combination of multiple attributes that establish or strengthen a positive store image (Theodoridis \& Chatzipanagiotou, 2009). Therefore, retail strategists are concentrating on various components to provide memorable customer experiences and enhance their loyalty to a retail store (Bustamante \& Rubio, 2017; Irfan, Siddiqui \& Ahmed, 2019).

Consequently, a key question for retail management is to identify the factors influencing satisfaction, to define and target customers' segments, and to provide long-term support (Sivadas \& Baker-Prewitt, 2000). The concept of market segmentation was first introduced by Smith (1956), who found that market segmentation contained different and specific homogeneous markets, according to consumers' various preferences and desires. Consequently, consumers can be grouped in different ways based on geographic, demographic, psychographic and behavioural factors (Kotler \& Keller, 2015). In that context, demographic factors are most frequently applied when segmenting customer groups, and comprise age, gender, family size, education, income, occupation, religion, race, ethnicity, generation and nationality. There are primarily two reasons behind this. First, consumer needs, wants and usage rates are often related to demographic variables. Secondly, demographic information is widely available (Lamb, Hair \& McDaniel, 2011) and it is easier to measure these variables compared to other types of variables (Kotler \& Armstrong, 2010; Kotler, Armstrong, Harris \& Piercy, 2017).

The paper examines customer satisfaction with various retail store elements in food retailing in Croatia. The main purpose of this study was to identify different consumer segments by their level of satisfaction with various retail store elements and to define the profile of each segment. To achieve this, latent class analysis (LCA) was used. The goal of LCA is to define the smallest number of classes that is adequate to explain the associations observed between the manifest variables. Additionally, limited empirical evidence gathered from the Croatian retail sector was another motivation for conducting this research.

In the context of food retailing, there is a lack of studies integrating satisfaction with retail store elements and customer segmentation. Therefore, this study contributes to existing literature by providing valuable insights into different consumer segments based on their level of satisfaction with retail store context in food retailing in Croatia. Additionally, the characteristics of each cluster are described, providing useful insights into different consumer profiles that might help retailers in building and managing relationships with consumers, and enhancing their satisfaction. Consequently, we propose practical directions to target specific consumer segments more efficiently. The results of our study might assist retail managers and food marketeers to develop and implement marketing strategies more effectively and to tailor promotional activities to meet the needs of a particular consumer segment.

This paper is divided into five parts. The section that follows introduction outlines bodies of literature referring to market segmentation, cus-

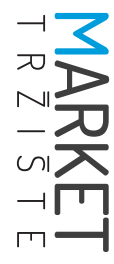


tomer satisfaction and store attributes in the retail environment. The methodology of research and data analysis is outlined in the following section, while the fourth section presents research results and discussion. Finally, the last section provides conclusions as well as research limitations and propositions for future work.

\section{THEORETICAL FRAMEWORK}

As regards the retail environment, there is a mounting pressure to be competitive. To operate and survive in such an environment, retailers should pay particular attention to strategies of 4Cs, namely, customer solution, customer cost, convenience and communication (Lauterborn, 1990; Kotler \& Armstrong, 2010; Kotler, Armstrong, Harris \& Piercy, 2017). In early twenty-first century, customer satisfaction was addressed as a part of customer relationship management (Sunder, 2011). Understanding different consumer segments is essential for both retailers and marketeers in order to approach them and maintain competitive advantage. In particular, retailers are aware of the significance of customer satisfaction on the outcome of their marketing and commercial strategies, as they strive to attract new consumers and keep the existing ones.

It is common knowledge that customer satisfaction is a relative concept (Hill, Brierley \& MacDougallt, 2003). Broadly speaking, marketing literature distinguishes two types of customer satisfaction, i.e. transaction-specific satisfaction and overall or cumulative satisfaction (Theodoridis \& Chatzipanagiotou, 2009; Oliver, 2014). Transaction-specific satisfaction emerges from a single service transaction and is seen as a post-choice evaluation of a specific purchase occasion (Oliver, 1980). On the other hand, the overall satisfaction provides a holistic view and arises out of a continually updated cumulative satisfaction (Sunder, 2011), indicating that satisfaction is derived from a range of experiences with a specific product during a given period (Anderson, Fornell \& Lehmann, 1994).
In the literature on the subject, customer satisfaction or dissatisfaction is defined as the feeling consumers have about the degree to which their experiences with an organisation respond to their needs (Hill, Roche \& Allen, 2007). SimilarIy, Calvert (2006) emphasises that decision that have to do with satisfaction are more affective with emotional reactions to an experience or a collection of experiences. In addition, Hill \& Alexander (2006) stress that customer satisfaction is in the customer's mind, suggesting that customer's attitude may or may not match the actual situation. In particular, the importance of emotions in building customer satisfaction in the retail landscape is often outlined (Burns \& Neisner, 2006). It is well known that customer's satisfaction with a store is one of the most important drivers of loyalty to the particular store (McDougall \& Levesque, 2000; Martinelli \& Balboni, 2012; Kumar, Dalla Pozza \& Ganesh, 2013). In the context of promoting store loyalty, Sivadas and Baker\&Prewitt (2000) outline the importance of fostering favourable relative attitude and customers' recommendations.

In general, the factors affecting customer satisfaction are mostly related to various store attributes, such as physical environment, in-store convenience, personnel, atmosphere, store service, product assortment, product quality and pricing policy (Grewal, Berry \& Seiders, 2002; Juhl, Kristensen \& Ostergaard, 2002; Anselmsson, 2006; Pan \& Zinkhan, 2006; Ganesh, Reynolds \& Luckett, 2007; Huddleston, Whipple, Mattick \& Lee, 2009; Martinez-Ruiz, Jimenez-Zarco \& Izquierdo-Yusta, 2010). In that context, previous studies have also identified diverse moderating variables such as age, gender, education, income, etc. (Mittal \& Kamakura, 2001; Seiders, Voss, Grewal \& Godfrey, 2005). The majority of studies have demonstrated a positive relationship between store loyalty and both consumer satisfaction and store atmosphere (Francioni, Savelli \& Cioppi, 2018).

On a wider level, market segmentation divides consumers into diverse groups, within which customers have a common interest in the same, 
or similar, set of needs (McDonald \& Dunbar, 2012). In the retail sector, customers assess a retailer's offer by fusing all the above-mentioned attributes to determine their satisfaction level (Pan \& Zinkhan, 2006). Established on the general evaluation of all store attributes influencing customers' behaviour in the store, distinct sub-clusters of customers with various degrees of satisfaction can be determined (Morschett, Swoboda, \& Foscht, 2005).

As regards food retailing, various consumer groups have been identified according to a number of factors. They include purchasing frequency (Carpenter \& Moore, 2006; Calvo-Porral \& Levy-Mangin, 2017), attitudes to store features and shopping behaviour (Ness, Gorton \& Kuznesof, 2002; Bourlakis, Ness \& Vasilios Priporas, 2006), length, recency, frequency, monetary and periodicity factors (Peker, Kocyigit \& Eren, 2017), consumers' decision-making styles in food-product context (Anić, Rajh \& Piri Rajh, 2015), food-related lifestyle (Kesić \& Piri Rajh, 2003; Kesić, Piri Rajh \& Kesić, 2008; Kesić \& Piri Rajh, 2009), satisfaction with sales staff and store design (Mihić, 2006), affective and cognitive variables (Mihić, 2002), the level of environmental responsibility (Ham, 2009) and segmentation of urban market customers (Kovačić, Radman, \& Haas, 2002).

Based on literature review, it can be concluded that there is a lack of studies addressing both satisfaction with retail store elements and their subsequent segmentation in the context of food retailing. Consequently, we propose the following research hypothesis:

$\mathrm{H1}$ : According to their level of satisfaction with retail store attributes, different segments of consumers can be identified in Croatian food retailing.

\section{DATA AND METHODOLOGY}

To accomplish the central goal of this paper, the empirical research was made on a conve- nience sample of 500 respondents from the Dubrovnik-Neretva County. The research was carried out during the period from $1^{\text {st }}$ June to $1^{\text {st }}$ October 2016 by personal interview. Of the original sample, 469 questionnaires were correctly finalised giving a response rate of $93.8 \%$. The profile of the sample is presented in Table 1. Data were accumulated through a highly structured questionnaire that consisted of questions formed on the analysis of the existing literature and former research in this field (Mihić, 2006; Mihić \& Kursan, 2010).

The survey consisted of three parts. The first part deals with the satisfaction of respondents through six dimensions in a retail store context. These dimensions are retail service quality, retail store quality, store atmosphere, product assortment, price and additional services. Every dimension is characterised by several items. The total of 38 items were distributed into five components. The questionnaire consisted of multiple-choice questions applying a Likert scale (1 - completely dissatisfied; 5 - completely satisfied), where respondents stated their level of satisfaction with a given statement. The second part included behavioural characteristics of respondents, store type and buying frequency. Type of store was measured on ordinal scale according to Gupta and Randhawa (2008) (1 - convenience store, 2 - supermarket, 3 - hypermarket), whereas buying frequency was measured on ordinal scale from 1 to 3 (i.e. daily, weekly, biweekly) according to Sharma (2019). The socio-demographic characteristics of the respondents (gender, age, education, occupation and monthly income in HRK) were analysed in the third part of the survey.

To reach the key objective of this paper, descriptive, inferential and multivariate statistics have been used. In the descriptive part, mean values, as well as standard deviation, frequencies and items total correlation values were measured in order to eliminate the statements which did not fit in the set criterion, which was necessary for further analysis. Secondly, in order to verify the dimensionality of the construct defined by 
items, exploratory factor analysis with Varimax rotation was used. Finally, scale evaluations were measured when applying latent class analysis (criterion and construct validity). Lazarsfeld (1950) introduced latent class model, whereas Green, Carmone and Wachspress (1976) were the first to apply it to market segmentation. In market segmentation, Latent Class models (hereafter LC models) determine unobserved heterogeneity among population with the purpose of discovering substantively meaningful groups of people with related answers to evaluate variables formed on a probability (Nylund, Muthen \& Asparouhov, 2007; Hamka, Bouwman, de Reuver \& Kroesen, 2014).

Latent class models estimate the parameters of the class membership model and clarify how, conditional on a certain class, an individual will

TABLE 1: Respondents' profile

\begin{tabular}{|c|c|c|}
\hline Demographic characteristics & Frequency & Percentage (\%) \\
\hline $\begin{array}{l}\text { Age } \\
18-34(1) \\
35-49(2) \\
50-64(3) \\
65 \text { and over (4) }\end{array}$ & $\begin{array}{l}150 \\
149 \\
128 \\
42\end{array}$ & $\begin{array}{c}32.0 \\
31.8 \\
27.3 \\
9.0\end{array}$ \\
\hline $\begin{array}{l}\text { Gender } \\
\text { Male (1) } \\
\text { Female (2) }\end{array}$ & $\begin{array}{l}224 \\
245\end{array}$ & $\begin{array}{l}47.8 \\
52.2\end{array}$ \\
\hline $\begin{array}{l}\text { Education } \\
\text { Primary school or less (1) } \\
\text { High school (2) } \\
\text { Bachelor degree (3) } \\
\text { Graduate degree (4) } \\
\text { Postgraduate (5) }\end{array}$ & $\begin{array}{c}12 \\
212 \\
132 \\
102 \\
11\end{array}$ & $\begin{array}{c}2.6 \\
45.2 \\
28.1 \\
21.7 \\
2.3\end{array}$ \\
\hline $\begin{array}{l}\text { Occupation } \\
\text { Public sector (1) } \\
\text { Private sector (2) } \\
\text { Private businessman (3) } \\
\text { Farmer (4) } \\
\text { Housekeeper (5) } \\
\text { Student (6) } \\
\text { Retired (7) } \\
\text { Unemployed (8) }\end{array}$ & $\begin{array}{l}100 \\
142 \\
39 \\
14 \\
27 \\
67 \\
69 \\
11\end{array}$ & $\begin{array}{c}21.3 \\
30.3 \\
8.3 \\
3.0 \\
5.8 \\
14.3 \\
14.7 \\
2.4 \\
\end{array}$ \\
\hline $\begin{array}{l}\text { Monthly income in HRK } \\
\text { Under 3,000 (1) } \\
3,001-4,000(2) \\
4,001-6,000(3) \\
6,001-8,000(4) \\
8,001-10,000(5) \\
10,001-(6)\end{array}$ & $\begin{array}{c}91 \\
107 \\
154 \\
84 \\
24 \\
9\end{array}$ & $\begin{array}{c}19.4 \\
22.8 \\
32.8 \\
17.9 \\
5.1 \\
1.9\end{array}$ \\
\hline
\end{tabular}

Source: Authors' research

${ }^{1}$ HRK stands for Croatian Kuna. In January 2016 exchange rate of EUR 1 to HRK was 7.515 (https://www.hnb.hr/en/web/ guest/core-functions/monetary-policy/exchange-rate-list/exchange-rate-list, accessed January 30th 2017.). 
TABLE 2: Dimensions, inferential statistics and reliability analysis of the scale items

\begin{tabular}{|c|c|c|c|c|c|c|c|c|}
\hline & $\begin{array}{l}\text { Item total } \\
\text { correlation }\end{array}$ & Mean & SD & 1 & 2 & 3 & 4 & 5 \\
\hline \multicolumn{9}{|c|}{ RETAIL SERVICE QUALITY (RSerQ) $a=0.658 a=0.681$} \\
\hline Courtesy of store personnel (q1) & 0.442 & 3.65 & 0.693 & 0.2 & 3 & 37.5 & 50.3 & 9 \\
\hline $\begin{array}{l}\text { Helpfulness of store personnel } \\
\text { (q2) }\end{array}$ & 0.423 & 3.66 & 0.786 & 1.3 & 3.8 & 34.1 & 48.8 & 11.9 \\
\hline Sincerity of store personnel (q3) & 0.328 & 3.4 & 0.807 & 1.3 & 8.5 & 47.1 & 35 & 8.1 \\
\hline Education of store personnel (q4) & 0.437 & 3.45 & 0.71 & 1.3 & 6.2 & 41.6 & 48.2 & 2.8 \\
\hline Tidiness (q5) & 0.39 & 3.9 & 0.734 & 0.2 & 2.8 & 23 & 55.2 & 18.8 \\
\hline Efficiency of store personnel (q6) & 0.41 & 3.66 & 0.73 & 0.2 & 5.5 & 31.8 & 53.3 & 9.2 \\
\hline $\begin{array}{l}\text { Promptness at the cash registers } \\
\text { (q7) }\end{array}$ & 0.317 & 3.41 & 0.821 & 0.6 & 11.5 & 42.2 & 37.5 & 8.1 \\
\hline \multicolumn{9}{|c|}{ RETAIL STORE QUALITY (RStQ) $\alpha=0.776 \alpha=0.792$} \\
\hline Store layout (q8) & 0.466 & 3.64 & 0.802 & 2.8 & 2.1 & 33.9 & 51.2 & 10 \\
\hline Cleanliness of store (q9) & 0.367 & 3.87 & 0.754 & & 4.3 & 23 & 54.4 & 18.3 \\
\hline Store location (q10) & 0.444 & 3.75 & 0.666 & & 3.4 & 27.3 & 59.9 & 9.4 \\
\hline Number of stores (q11) & 0.339 & 3.66 & 0.719 & 1.5 & 3 & 30.9 & 57.6 & 7 \\
\hline Store hours (q12) & 0.464 & 3.85 & 0.768 & 1.5 & 1.9 & 23.5 & 56.5 & 16.6 \\
\hline Parking facilities (q13) & 0.454 & 3.48 & 0.703 & & 4.1 & 52 & 35.8 & 8.1 \\
\hline Store exterior appearance (q14) & 0.407 & 3.46 & 0.68 & & 5.3 & 48.2 & 41.2 & 5.3 \\
\hline In-store attractiveness (q15) & 0.527 & 3.4 & 0.693 & & 5.3 & 55.7 & 32.4 & 6.6 \\
\hline In-store aisle width (q16) & 0.517 & 3.51 & 0.856 & 2.6 & 5.8 & 40.5 & 40.5 & 10.7 \\
\hline In-store ease of navigation (q17) & 0.512 & 3.6 & 0.823 & 0.9 & 9.2 & 29.4 & 50.5 & 10 \\
\hline Cash register organization (q18) & 0.431 & 3.5 & 0.813 & 1.7 & 7.7 & 37.3 & 45.6 & 7.7 \\
\hline \multicolumn{9}{|c|}{ STORE ATMOSPHERE (SA) $a=0.704$} \\
\hline In-store atmosphere (q19) & 0.524 & 3.55 & 0.704 & & 5.1 & 42.4 & 45.2 & 7.2 \\
\hline Illumination (q20) & 0.499 & 3.74 & 0.797 & 0.6 & 2.8 & 35.6 & 43.5 & 17.5 \\
\hline Scent (q21) & 0.545 & 3.4 & 0.807 & 1.1 & 8.7 & 47.5 & 34.1 & 8.5 \\
\hline \multicolumn{9}{|c|}{ PRODUCT ASSORTMENT (PA) $\alpha=0.789 a=0.808$} \\
\hline Assortment (q22) & 0.578 & 3.65 & 0.814 & 3 & 2.6 & 30.9 & 53.3 & 10.2 \\
\hline Product quality (q23) & 0.512 & 3.75 & 0.721 & 0.2 & 5.1 & 24.7 & 59.1 & 10.9 \\
\hline $\begin{array}{l}\text { Placement of products on } \\
\text { shelves }(q 24)\end{array}$ & 0.326 & 3.61 & 0.712 & 0.2 & 6 & 33 & 53.9 & 6.8 \\
\hline Selection of local products (q25) & 0.594 & 3.43 & 0.844 & 0.4 & 12.4 & 40.5 & 37.1 & 9.6 \\
\hline $\begin{array}{l}\text { Selection of retail store brands } \\
\text { (q26) }\end{array}$ & 0.387 & 3.58 & 0.689 & & 4.5 & 39.7 & 48.8 & 7 \\
\hline $\begin{array}{l}\text { Selection of bread and gourmet } \\
\text { products (q27) }\end{array}$ & 0.585 & 3.59 & 0.761 & 1.1 & 4.9 & 36.2 & 49 & 8.7 \\
\hline $\begin{array}{l}\text { Selection of fresh fruit and } \\
\text { vegetables (q28) }\end{array}$ & 0.482 & 3.51 & 0.828 & 2.3 & 4.5 & 43.1 & 39.9 & 10.2 \\
\hline $\begin{array}{l}\text { Selection of health products } \\
\text { (q29) }\end{array}$ & 0.520 & 3.09 & 0.892 & 6 & 14.5 & 47.3 & 29 & 3.2 \\
\hline
\end{tabular}




\begin{tabular}{|l|c|c|c|c|c|c|c|c|}
\hline & $\begin{array}{c}\text { Item total } \\
\text { correlation }\end{array}$ & Mean & SD & $\mathbf{1}$ & $\mathbf{2}$ & $\mathbf{3}$ & $\mathbf{4}$ & $\mathbf{5}$ \\
\hline Selection of fresh meat (q30) & 0.534 & 3.32 & 0.793 & 2.6 & 7.5 & 50.5 & 34.1 & 5.3 \\
\hline
\end{tabular}

\section{PRICE (PR) $\mathbf{a}=\mathbf{0 . 7 9 3}$}

\begin{tabular}{|c|c|c|c|c|c|c|c|c|}
\hline Price level (q31) & 0.449 & 3.12 & 0.868 & 3.6 & 16.6 & 49 & 25.8 & 4.9 \\
\hline Signage/readability (q32) & 0.549 & 3.3 & 0.767 & 1.7 & 9.2 & 50.5 & 34.1 & 4.5 \\
\hline Price credibility (q33) & 0.610 & 3.33 & 0.77 & 0.9 & 9.6 & 51.6 & 31.6 & 6.4 \\
\hline $\begin{array}{l}\text { Frequency of price promotions } \\
\text { (q34) }\end{array}$ & 0.557 & 3.43 & 0.815 & 0.6 & 13.4 & 34.1 & 46.3 & 5.5 \\
\hline $\begin{array}{l}\text { Quality of product promotion } \\
\text { (q35) }\end{array}$ & 0.519 & 3.33 & 0.756 & 1.7 & 9.8 & 45 & 40.9 & 2.6 \\
\hline $\begin{array}{l}\text { Value offered equal to price } \\
\text { charged (q36) }\end{array}$ & 0.603 & 3.16 & 0.899 & 3.2 & 18.8 & 42.4 & 30.3 & 5.3 \\
\hline \multicolumn{9}{|c|}{ ADDITIONAL SERVICES (AS) $\mathbf{a}=0.679$} \\
\hline Bill payment (q37) & 0.413 & 3.06 & 0.749 & 3.4 & 13.9 & 57.1 & 24.5 & 1.1 \\
\hline Home delivery (q38) & 0.413 & 2.58 & 0.882 & 14.5 & 23.5 & 52.2 & 9 & 0.9 \\
\hline
\end{tabular}

Source: Authors' research

behave, and present the estimates of the segments size (Sell, Mezei \& Walden, 2014). In this analysis, individual consumers were chosen for the observations. They were grouped together according to their observed level of satisfaction measured on a five-point Likert scale. Individuals' satisfaction was investigated with respect to different retail store elements using LatentGOLD 5.1 software.

\section{RESULTS AND DISCUSSION}

Respondents' profiles are presented in Table 1.

As regards the gender structure, more than 50\% of the respondents were female. Almost $64 \%$ of respondents were in the category group from 18 to 49 years of age, and one-fourth included respondents from 50 to 64 years of age. The educational structure showed that almost half of the sample (45.2\%) finished high school, while 52\% were highly educated. Furthermore, just over $60 \%$ of respondents were employed, with almost $40 \%$ of them engaged in private businesses. Approximately three quarters of the respondents had monthly income under HRK 6,001.
Dimensions and reliability analysis of the scale items of different retail store attributes are presented in columns one to four of Table 2. Item reliability was tested by applying item-total correlation values and Cronbach's alpha coefficients. In the same table, columns five to nine show the frequency distributions of the answers to every attitude statements, as well as their means and standard deviations. When applying reliability analysis, four items were removed ( $q 3$, q7, q11, q24). By deleting these statements Cronbach's alpha coefficient increased from 0.658 to 0.681 in the first dimension, from 0.776 to 0.792 for the second dimension, and from 0.789 to 0.808 for the fourth dimension. Once the elimination was done, thirty-four statements were utilised for further analysis. The respondents had maximum average level of agreement with the dimension tagged retail service quality (3.664) and the lowest level of agreement with the dimensions price (3.27), and additional services (2.82).

The quality of retail store tidiness was marked with the highest grade (3.9). The highest level of standard deviation was found in the statement "value offered equal to price charged" and it 
TABLE 3: Factor loadings

\begin{tabular}{|c|c|c|c|c|c|}
\hline & & & actors & & \\
\hline Statements & PA & $P R$ & SA & RStQ & RSerQ \\
\hline $\mathrm{q} 1$ & 0.072 & -0.045 & 0.178 & 0.159 & 0.732 \\
\hline$q 2$ & 0.339 & -0.021 & 0.185 & 0.171 & 0.697 \\
\hline$q 4$ & 0.033 & 0.283 & -0.133 & 0.069 & 0.549 \\
\hline $\mathrm{q} 5$ & 0.047 & 0.15 & 0.358 & -0.159 & 0.593 \\
\hline q6 & 0.162 & 0.095 & 0.335 & -0.01 & 0.441 \\
\hline q8 & 0.126 & 0.253 & 0.24 & 0.333 & 0.244 \\
\hline q9 & 0.005 & 0.155 & -0.015 & 0.613 & 0.425 \\
\hline q10 & 0.052 & -0.19 & 0.243 & 0.444 & 0.25 \\
\hline$q 12$ & 0.168 & 0.008 & 0.14 & 0.63 & 0.16 \\
\hline q13 & 0.105 & 0.028 & 0.052 & 0.697 & -0.005 \\
\hline q14 & -0.01 & 0.348 & -0.013 & 0.611 & 0.083 \\
\hline q15 & 0.393 & 0.096 & 0.349 & 0.506 & 0.12 \\
\hline q16 & 0.144 & -0.132 & 0.114 & 0.715 & 0.041 \\
\hline $\mathrm{q} 17$ & 0.021 & 0.237 & 0.081 & 0.654 & -0.04 \\
\hline q18 & 0.184 & 0.088 & 0.286 & 0.634 & 0.019 \\
\hline q19 & 0.25 & 0.07 & 0.683 & 0.241 & -0.015 \\
\hline $\mathrm{q} 20$ & 0.165 & 0.13 & 0.701 & 0.237 & 0.039 \\
\hline $\mathrm{q} 21$ & 0.163 & 0.182 & 0.454 & 0.365 & 0.128 \\
\hline $\mathrm{q} 22$ & 0.683 & 0.345 & 0.16 & -0.026 & 0.15 \\
\hline q23 & 0.442 & 0.314 & 0.409 & 0.057 & 0.065 \\
\hline q25 & 0.416 & 0.333 & 0.098 & 0.195 & -0.093 \\
\hline $\mathrm{q} 26$ & 0.608 & 0.138 & 0.085 & 0.24 & -0.166 \\
\hline $\mathrm{q} 27$ & 0.727 & 0.225 & 0.061 & 0.03 & 0.058 \\
\hline $\mathrm{q} 28$ & 0.716 & 0.107 & 0.15 & -0.16 & 0.163 \\
\hline q29 & 0.629 & 0.155 & -0.084 & 0.162 & 0.285 \\
\hline $\mathrm{q} 30$ & 0.632 & 0.171 & -0.012 & 0.048 & 0.288 \\
\hline q31 & 0.199 & 0.663 & 0.103 & 0.078 & 0.049 \\
\hline $\mathrm{q} 32$ & -0.059 & 0.696 & 0.232 & 0.087 & 0.123 \\
\hline q33 & 0.205 & 0.698 & 0.1 & 0.101 & 0.005 \\
\hline q34 & 0.381 & 0.442 & -0.217 & 0.047 & 0.094 \\
\hline q35 & 0.359 & 0.572 & 0.108 & -0.043 & 0.117 \\
\hline q36 & 0.292 & 0.694 & 0.001 & 0.033 & 0.004 \\
\hline q37 & 0.194 & 0.288 & 0.06 & 0.305 & 0.37 \\
\hline $\mathrm{q} 38$ & 0.293 & 0.281 & -0.044 & -0.05 & 0.299 \\
\hline Cronbach's Alpha & 0.681 & 0.792 & 0.704 & 0.808 & 0.800 \\
\hline Percentage of variance extracted (\%) & 12.908 & 9.703 & 9.652 & 8.816 & 8.365 \\
\hline \multicolumn{3}{|c|}{ Kaiser-Meyer-Olkin Measure of Sampling Adequacy. } & \multicolumn{3}{|r|}{0.830} \\
\hline \multicolumn{3}{|l|}{ Bartlett's Test of Sphericity } & \multicolumn{3}{|r|}{0.000} \\
\hline
\end{tabular}


amounted to 0.899, which reveals a discrepancy between respondents' opinion when taking into consideration the issues related to the customer's level of satisfaction.

In Table 3 estimated factor loadings describe five factors. Statements with factor loading less than 0.5 were excluded from further analysis (q6, q8, q10, q21, q23, q25, q34, q37, and q38). According to Hair, Black, Balin and Anderson (2010), an acceptable factor loading value is more than 0.5. Additional services, such as dimension, did not fulfil the criteria, so exploratory factor analysis in comparison with Table 2 distributed the statements into five acceptable dimensions-factors - product assortment (PA), price (PR), store atmosphere (SA), retail store quality (RStQ) and retail service quality (RSerQ). The KMO evaluation of sampling adequacy was 0.830 , which was found to be appropriate for factor analysis, and the outcome of Bartlett Test of Sphericity was significant at 0.000 confidence level. Scale reliability was measured using Cronbach's alpha coefficient, resulting in above 0.6 for all factors, which exceeds Peterson (1994) recommendation.

Factor scores from Table 4 were applied as indicators in the latent class model. A set of latent class cluster models with a growing number of classes were estimated. According to $p$ values associated with $L^{2}$ statistic that presents the level of relation between the variables that were unexplained after model estimation (Ramirez-Hurtado \& Berbel-Pineda, 2014), it was found that three models fit better than others, i.e. models with four, five and six latent classes. For the values of $\mathrm{L}^{2}$ statistics results were lowest in Model 5. In addition, a five-cluster model displays minimum BIC index (Vermunt \& Magidson, 2005). Therefore, results indicate the best solution of five consumer segments that minimize the BIC index - 3936,887. The Wald test in Table

TABLE 4: Estimation of the model - selection of latent clusters

\begin{tabular}{|l|l|r|r|r|r|r|r|r|r|}
\hline & & \multicolumn{1}{|c|}{ LL } & BIC(LL) & CAIC(LL) & Npar & $\mathbf{L}^{2}$ & df & p-value & $\begin{array}{c}\text { Class. } \\
\text { Err. }\end{array}$ \\
\hline Model1 & 1-Cluster & -2095.43 & 4289.27 & 4305.27 & 16 & 3806.892 & 453 & 0.000 & 0 \\
\hline Model2 & 2-Cluster & -1920.74 & 4013.703 & 4041.703 & 28 & 3457.519 & 441 & 0.000 & 0.0418 \\
\hline Model3 & 3-Cluster & -1876.07 & 3998.173 & 4038.173 & 40 & 3368.182 & 429 & 0.020 & 0.0309 \\
\hline Model4 & 4-Cluster & -1818.72 & 3957.269 & 4009.269 & 52 & 3253.47 & 417 & 0.114 & 0.0613 \\
\hline Model5 & 5-Cluster & -1771.62 & 3936.887 & 4000.887 & 64 & 3159.28 & 405 & 0.092 & 0.0306 \\
\hline Model6 & 6-Cluster & -1737.3 & 3942.045 & 4018.045 & 76 & 3190.631 & 393 & 0.070 & 0.0649 \\
\hline Model7 & 7-Cluster & -1685.71 & 3942.673 & 4020.673 & 88 & 2987.452 & 381 & 0.043 & 0.0646 \\
\hline
\end{tabular}

Source: Authors' research

TABLE 5: Model for indicators

\begin{tabular}{|l|r|r|r|r|r|r|r|c|}
\hline & \multicolumn{1}{|c|}{ Cluster1 } & Cluster2 & Cluster3 & Cluster4 & Cluster5 & Wald & p-value & R2 \\
\hline RSerQ & -0.2549 & -2.9594 & 2.8444 & -0.9972 & 1.3672 & 74.1989 & 0.000 & 0.3251 \\
\hline RStQ & 2.2986 & -6.2107 & 8.7102 & -0.9069 & -3.8912 & 39.1453 & 0.000 & 0.5999 \\
\hline SA & 0.6945 & -1.7332 & 2.135 & 0.4584 & -1.5546 & 45.4405 & 0.000 & 0.2768 \\
\hline PA & 2.8594 & -4.8711 & 8.7778 & -4.9536 & -1.8126 & 15.5343 & 0.0037 & 0.5245 \\
\hline PR & -0.3893 & -2.3593 & 5.7446 & -5.2819 & 2.2859 & 65.9536 & 0.000 & 0.3998 \\
\hline
\end{tabular}

Source: Authors' research 
5 shows that all exploratory variables, e.g. factors are significant for the model $(p<0.05)$.

As a result of the analysis, the latent variable can be described by means of the five classes of consumers, each with a different level of satisfaction with each of the classes, that is big enough to be considered relevant for the purpose of analysis, with relevant consumers' profiles marked as different. The five customers segments are convenience-oriented, disinterested, assortment-oriented, price-sensitive and grey consumers.

As can be seen from Table 6, the largest cluster (Cluster 1) that was given the title convenience-oriented consumers comprises $59.6 \%$ of consumers $(n=280)$, who are, in general, just about satisfied (3.67). These consumers expressed the highest level of satisfaction (3.82) with retail store quality, including store cleanliness, store working hours, parking facilities, store exterior appearance, in-store attractiveness, instore aisle width, in-store ease of navigation and cash register organization. In contrast, convenience-oriented consumers expressed the lowest level of satisfaction (3.42) with prices in stores (price level, signage/readability, price credibility, quality of product promotion and value offered equal to price charged). Almost $65 \%$ of them buy in supermarkets and half of them (48.8\%) on a daily basis. Regarding gender, women and men are equally distributed and more than one third of them belong to the age group between 35 and 49 years of age. The total of $43.9 \%$ of surveyed customers have completed high school, and one quarter of customers had a personal monthly income of above HRK 6,001. Although convenience-oriented consumers can be regarded as the ones mostly satisfied with all retail store elements, in this context retail managers should focus on their pricing strategy.

The second cluster were disinterested consumers and it comprises $18.4 \%$ of respondents $(n=87)$ who are neither satisfied nor dissatisfied (2.97) with all the offered retail store elements. They predominantly buy in supermarkets (57.8\%) once a week (47.2\%). They are mostly young respondents between 18 and 34 years of age, equally male and female, with bachelor's degree and personal monthly income between HRK 4,001 and 6,000. Disinterested consumers are least satisfied with product assortment (2.85). This result might seem unexpected, given that just under one-third of them usually buys in hypermarkets, which provide broad product assortment with wide offerings. However, previous research indicates that perceived assortment is greater when the items in the assortment are different, the category occupies more space, and the customer's favourite product is available (Levy, Weitz \& Grewal, 2012). For this reason, determining the composition of product assortment in every category is a critical issue faced by retailers (Dass \& Kumar, 2012). Therefore, in order to attract disinterested consumers, retailers should carefully choose the right product assortment and create a product assortment strategy.

The third cluster of assortment-oriented consumers includes $7.9 \%$ of the respondents $(n=37)$, who are satisfied (4.21) with all the retail store elements. They showed the highest level of satisfaction with product assortment (4.34) which means assortment, selection of retail store brands, selection of bread and gourmet products, selection of fresh fruit and vegetables, selection of health products and fresh meat. They exposed the lowest level of satisfaction with prices in stores (4.05) including the following elements: price level, signage/readability, price credibility, quality of product promotion and value offered equal to price charged. They usually buy in supermarkets (67.1\%) on a daily basis (61.2\%). Assortment-oriented consumers are mostly young respondents between 18 and 34 years of age (46.5\%), mostly female who completed high school (70.8\%) and with personal monthly income between HRK 3,001 and 4,000. In terms of their low levels of satisfaction with prices, retail managers could enhance their satisfaction by stimulating customer demand through different promotion instruments.

The fourth cluster of price-sensitive consumers encompasses $7.7 \%$ of the respondents $(n=36)$.

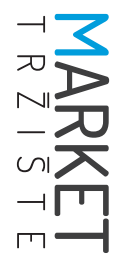


TABLE 6: Description of segments

\begin{tabular}{|c|c|c|c|c|c|}
\hline & Cluster1 & Cluster2 & Cluster3 & Cluster4 & Cluster5 \\
\hline Cluster Size & 0.5963 & 0.1843 & 0.0799 & 0.0777 & 0.0618 \\
\hline \multicolumn{6}{|l|}{ Indicators } \\
\hline \multicolumn{6}{|l|}{ RSerQ } \\
\hline Dissatisfied & 0.0019 & 0.0835 & 0 & 0.0066 & 0.0001 \\
\hline Neither satisfied nor dissatisfied & 0.2674 & 0.7763 & 0.0127 & 0.4334 & 0.0642 \\
\hline Satisfied & 0.7211 & 0.1401 & 0.7617 & 0.5565 & 0.8765 \\
\hline Completely satisfied & 0.0096 & 0.0001 & 0.2256 & 0.0035 & 0.0592 \\
\hline Mean & 3.7384 & 3.0568 & 4.2128 & 3.557 & 3.9949 \\
\hline \multicolumn{6}{|l|}{ RStQ } \\
\hline Dissatisfied & 0 & 0.0224 & 0 & 0.0001 & 0.0022 \\
\hline Neither satisfied nor dissatisfied & 0.173 & 0.9767 & 0.0002 & 0.8377 & 0.9881 \\
\hline Satisfied & 0.8264 & 0.0009 & 0.7103 & 0.1622 & 0.0097 \\
\hline Completely satisfied & 0.0006 & 0 & 0.2895 & 0 & 0 \\
\hline Mean & 3.8275 & 2.9786 & 4.2892 & 3.1621 & 3.0075 \\
\hline \multicolumn{6}{|l|}{ SA } \\
\hline Dissatisfied & 0.0063 & 0.1436 & 0.0004 & 0.0092 & 0.1205 \\
\hline Neither satisfied nor dissatisfied & 0.3729 & 0.7556 & 0.097 & 0.4332 & 0.7583 \\
\hline Satisfied & 0.5586 & 0.0999 & 0.6138 & 0.5125 & 0.1198 \\
\hline Completely satisfied & 0.0622 & 0.001 & 0.2888 & 0.0451 & 0.0014 \\
\hline Mean & 3.6768 & 2.9583 & 4.191 & 3.5935 & 3.0021 \\
\hline \multicolumn{6}{|l|}{ PA } \\
\hline Completely dissatisfied & 0 & 0.0078 & 0 & 0.009 & 0 \\
\hline Dissatisfied & 0 & 0.1259 & 0 & 0.135 & 0.0066 \\
\hline Neither satisfied nor dissatisfied & 0.3032 & 0.8655 & 0.0008 & 0.8551 & 0.9725 \\
\hline Satisfied & 0.6958 & 0.0009 & 0.6594 & 0.0008 & 0.0209 \\
\hline Completely satisfied & 0.001 & 0 & 0.3398 & 0 & 0 \\
\hline Mean & 3.6977 & 2.8595 & 4.339 & 2.8477 & 3.0142 \\
\hline \multicolumn{6}{|l|}{ PR } \\
\hline Dissatisfied & 0.0045 & 0.0484 & 0 & 0.5093 & 0 \\
\hline Neither satisfied nor dissatisfied & 0.5693 & 0.8616 & 0.0027 & 0.488 & 0.0841 \\
\hline Satisfied & 0.4262 & 0.09 & 0.9455 & 0.0027 & 0.9143 \\
\hline Completely satisfied & 0.0001 & 0 & 0.0518 & 0 & 0.0016 \\
\hline Mean & 3.4219 & 3.0416 & 4.049 & 2.4934 & 3.9174 \\
\hline
\end{tabular}

\section{Covariates}

Retail store format

\begin{tabular}{|l|r|r|r|r|r|}
\hline Convenience store & 0.2449 & 0.1284 & 0.2688 & 0.9684 & 0.2801 \\
\hline Supermarket & 0.6446 & 0.5758 & 0.6711 & 0.0315 & 0.7115 \\
\hline Hypermarket & 0.1105 & 0.2958 & 0.0601 & 0.0002 & 0.0084 \\
\hline
\end{tabular}




\begin{tabular}{|c|c|c|c|c|c|}
\hline & Cluster1 & Cluster2 & Cluster3 & Cluster4 & Cluster5 \\
\hline Mean & 1.8656 & 2.1675 & 1.7913 & 1.0318 & 1.7284 \\
\hline \multicolumn{6}{|c|}{ Frequencies of purchase } \\
\hline Daily & 0.4888 & 0.4356 & 0.6126 & 0.8183 & 0.2372 \\
\hline Once a week & 0.412 & 0.4727 & 0.3292 & 0.1782 & 0.7278 \\
\hline Once in two weeks & 0.0992 & 0.0917 & 0.0582 & 0.0035 & 0.035 \\
\hline Mean & 1.6103 & 1.6561 & 1.4455 & 1.1852 & 1.7978 \\
\hline \multicolumn{6}{|l|}{ Age } \\
\hline $18-34$ & 0.2854 & 0.3556 & 0.4657 & 0.5948 & 0.0115 \\
\hline $35-49$ & 0.3599 & 0.3547 & 0.2183 & 0.1542 & 0.1319 \\
\hline $50-64$ & 0.2518 & 0.249 & 0.3026 & 0.25 & 0.5404 \\
\hline $65+$ & 0.1029 & 0.0407 & 0.0134 & 0.001 & 0.3163 \\
\hline Mean & 2.1722 & 1.9746 & 1.8637 & 1.6571 & 3.1615 \\
\hline \multicolumn{6}{|l|}{ Gender } \\
\hline $\mathrm{F}$ & 0.5069 & 0.5051 & 0.6216 & 0.4179 & 0.0001 \\
\hline $\mathrm{M}$ & 0.4931 & 0.4949 & 0.3784 & 0.5821 & 0.9999 \\
\hline Mean & 1.4931 & 1.4949 & 1.3784 & 1.5821 & 1.9999 \\
\hline \multicolumn{6}{|l|}{ Education } \\
\hline Primary school or less & 0.0226 & 0.0352 & 0 & 0.0715 & 0.0012 \\
\hline High school & 0.4399 & 0.3905 & 0.7084 & 0.335 & 0.5695 \\
\hline Bachelor degree & 0.2697 & 0.4366 & 0.1868 & 0.2514 & 0.0915 \\
\hline Graduate degree & 0.2356 & 0.1268 & 0.0779 & 0.3418 & 0.3377 \\
\hline Postgraduate & 0.0323 & 0.0109 & 0.0269 & 0.0002 & 0 \\
\hline Mean & 2.8151 & 2.6877 & 2.4232 & 2.8641 & 2.7657 \\
\hline \multicolumn{6}{|l|}{ Monthly income } \\
\hline Under 3.000 & 0.1992 & 0.1845 & 0.1854 & 0.339 & 0.0014 \\
\hline $3.001-4.000$ & 0.2288 & 0.2211 & 0.3953 & 0.2449 & 0.0055 \\
\hline $4.001-6.000$ & 0.3039 & 0.3635 & 0.2743 & 0.2872 & 0.5823 \\
\hline 6.001 plus & 0.2682 & 0.2309 & 0.145 & 0.1289 & 0.4108 \\
\hline Mean & 2.7583 & 2.7102 & 2.4477 & 2.2145 & 3.4121 \\
\hline
\end{tabular}

Source: Authors' research

They are neither satisfied nor dissatisfied (3.13) with retail store elements. They showed the lowest level of satisfaction with prices (2.49) which means with price level, signage/readability, price credibility, quality of product promotion and value offered equal to price charged. They often buy in convenience stores (96.8\%) on a daily basis (81.8\%). They are mostly young respondents from 18 to 34 years of age (59.4\%), male (58.2\%) with graduate degree (34.2\%) and personal monthly income from HRK 4,001 to 6,000 . According to their frequent visits to retailers, the customers in Cluster 4 exhibit a close relationship with a retailer. Not surprisingly, they are least satisfied with prices as they mainly buy in convenience stores (96.8\%) where prices are usually higher than at supermarkets (Lamb, Hair \& McDaniel, 2011). Additionally, a stronger emphasis could be put on store label goods, and retailers should use promotion events to support 
TABLE 7: Conditional probabilities

\begin{tabular}{|c|c|c|c|c|c|}
\hline & Cluster1 & Cluster2 & Cluster3 & Cluster4 & Cluster5 \\
\hline Overall & 0.5963 & 0.1843 & 0.0799 & 0.0777 & 0.0618 \\
\hline \multicolumn{6}{|l|}{ Indicators } \\
\hline \multicolumn{6}{|l|}{ RSerQ } \\
\hline Not satisfied & 0.2507 & 0.7277 & 0 & 0.0215 & 0.0001 \\
\hline Neither satisfied nor dissatisfied & 0.4542 & 0.4375 & 0.0085 & 0.0989 & 0.0008 \\
\hline Satisfied & 0.6995 & 0.0368 & 0.0926 & 0.071 & 0.1 \\
\hline Completely satisfied & 0.2712 & 0 & 0.7252 & 0 & 0.0036 \\
\hline \multicolumn{6}{|l|}{ RStQ } \\
\hline Not satisfied & 0 & 0.9998 & 0 & 0.0002 & 0 \\
\hline Neither satisfied nor dissatisfied & 0.2511 & 0.4391 & 0 & 0.1594 & 0.1503 \\
\hline Satisfied & 0.8771 & 0.0001 & 0.1004 & 0.0221 & 0.0004 \\
\hline Completely satisfied & 0.0055 & 0 & 0.9945 & 0 & 0 \\
\hline \multicolumn{6}{|l|}{ SA } \\
\hline Not satisfied & 0.0029 & 0.8537 & 0 & 0.0541 & 0.0893 \\
\hline Neither satisfied nor dissatisfied & 0.5032 & 0.2901 & 0.022 & 0.0623 & 0.1223 \\
\hline Satisfied & 0.7501 & 0.038 & 0.0995 & 0.105 & 0.0074 \\
\hline Completely satisfied & 0.5314 & 0.0614 & 0.3977 & 0.0096 & 0 \\
\hline \multicolumn{6}{|l|}{ PA } \\
\hline Completely dissatisfied & 0 & 0.0716 & 0 & 0.9284 & 0 \\
\hline Not satisfied & 0 & 0.7612 & 0 & 0.2388 & 0 \\
\hline Neither satisfied nor dissatisfied & 0.3863 & 0.3381 & 0.0001 & 0.1446 & 0.1308 \\
\hline Satisfied & 0.8866 & 0.0003 & 0.1116 & 0 & 0.0014 \\
\hline Completely satisfied & 0.0107 & 0 & 0.9893 & 0 & 0 \\
\hline \multicolumn{6}{|l|}{ PR } \\
\hline Not satisfied & 0.0005 & 0.2217 & 0 & 0.7778 & 0 \\
\hline Neither satisfied nor dissatisfied & 0.6368 & 0.2845 & 0.0001 & 0.0696 & 0.009 \\
\hline Satisfied & 0.6241 & 0.0469 & 0.1874 & 0.0004 & 0.1412 \\
\hline Completely satisfied & 0 & 0 & 1 & 0 & 0 \\
\hline \multicolumn{6}{|l|}{ Covariates } \\
\hline \multicolumn{6}{|l|}{ Retail store format } \\
\hline Convenience store & 0.5147 & 0.0833 & 0.0757 & 0.2653 & 0.061 \\
\hline Supermarket & 0.6509 & 0.1797 & 0.0908 & 0.0041 & 0.0745 \\
\hline Hypermarket & 0.5241 & 0.4335 & 0.0382 & 0.0001 & 0.0041 \\
\hline \multicolumn{6}{|l|}{ Frequency of purchase } \\
\hline Daily & 0.5842 & 0.1609 & 0.0981 & 0.1275 & 0.0294 \\
\hline Once a week & 0.5879 & 0.2084 & 0.0629 & 0.0331 & 0.1076 \\
\hline Once in two weeks & 0.7115 & 0.2033 & 0.0559 & 0.0032 & 0.026 \\
\hline Age & & & & & \\
\hline
\end{tabular}




\begin{tabular}{|c|c|c|c|c|c|}
\hline & Cluster1 & Cluster2 & Cluster3 & Cluster4 & Cluster5 \\
\hline $18-34$ & 0.5321 & 0.2049 & 0.1163 & 0.1445 & 0.0022 \\
\hline $35-49$ & 0.6758 & 0.2058 & 0.0549 & 0.0377 & 0.0257 \\
\hline $50-64$ & 0.5499 & 0.168 & 0.0885 & 0.0712 & 0.1223 \\
\hline $65+$ & 0.6853 & 0.0836 & 0.012 & 0.0009 & 0.2183 \\
\hline \multicolumn{6}{|l|}{ Gender } \\
\hline $\mathrm{F}$ & 0.633 & 0.1949 & 0.104 & 0.068 & 0 \\
\hline M & 0.5628 & 0.1745 & 0.0578 & 0.0866 & 0.1183 \\
\hline \multicolumn{6}{|l|}{ Education } \\
\hline Primary school or less & 0.5261 & 0.2535 & 0 & 0.2174 & 0.003 \\
\hline High school & 0.5802 & 0.1592 & 0.1252 & 0.0576 & 0.0779 \\
\hline Bachelor degree & 0.5715 & 0.2859 & 0.053 & 0.0695 & 0.0201 \\
\hline Graduate degree & 0.6459 & 0.1074 & 0.0286 & 0.1222 & 0.096 \\
\hline Postgraduate & 0.8215 & 0.0861 & 0.0917 & 0.0007 & 0 \\
\hline \multicolumn{6}{|l|}{ Monthly income } \\
\hline under 3.000 & 0.6122 & 0.1752 & 0.0763 & 0.1358 & 0.0004 \\
\hline $3.001-4.000$ & 0.598 & 0.1786 & 0.1384 & 0.0835 & 0.0015 \\
\hline $4.001-6.000$ & 0.5518 & 0.2039 & 0.0667 & 0.068 & 0.1096 \\
\hline 6.001 plus & 0.6411 & 0.1705 & 0.0464 & 0.0402 & 0.1018 \\
\hline
\end{tabular}

Source: Authors' research

their store brands. In general, store brand buyers are price-sensitive consumers who perceive a small quality gap between leading manufacturer brand and the store brand (Kumar \& Steenkamp, 2007; Garrido-Morgado, González-Benito \& Martos-Partal, 2016). However, retailers should be cautious about the frequency of promotions, as consumers might expect and anticipate periodic price reductions (Sivakumar, 2007).

Finally, the fifth cluster of grey consumers consists of $6.2 \%$ of indifferent respondents $(n=29)$ (3.38). They expressed the highest level of satisfaction with retail service quality (3.99), which includes the following: store personnel politeness, helpfulness and assistance from store personnel, and tidiness. In general, they buy in supermarkets (71.2\%) once a week (72.7\%). These grey consumers are mostly male, older than 50 (85.6\%), with high school diploma (56.9\%) and personal monthly income from HRK 4,001 to 6,000, although $41.1 \%$ of them have monthly income higher than HRK 6,001. Although Cluster 5 is the smallest segment among all groups (6.2\%), the growing importance of grey consumers cannot be ignored. The reason for this primarily lies in the $21^{\text {st }}$ century's dominant demographic phenomenon of population ageing (Bloom \& Luca, 2016). It affects a variety of sectors, including the retail industry, and particularly the food retail sector. Our results indicate that grey consumers are most satisfied with retail service quality. This supports previous findings in the literature suggesting that older consumers value in-store service (Parment, 2013) and emphasise the role of store personnel (Hare, Kirk \& Lang, 2001), in particular friendly and helpful staff (Meneely, Strugnell \& Burns, 2009). In addition, these consumers tend to spend more money at food stores than younger ones (Ong, Kitchen \& Jama, 2008).

The second tier of the respondents profile examination was preceded by the analysis of each variable and categories within each variable. The conditional probabilities are shown in Table 7. The results of the conditional probabilities regarding 


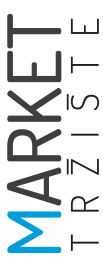

retail service quality, retail store quality and store atmosphere show that disinterested consumers have the highest probability of not being satisfied, convenience-oriented consumers have the highest probability of being satisfied and assortment-oriented consumers of being completely satisfied. Regarding product assortment, price-sensitive consumers show the highest probability of being completely dissatisfied, disinterested consumers of not being satisfied and convenience-oriented consumers of being satisfied. Finally, assortment-oriented consumers show the highest probability of being completely satisfied. In terms of price, the highest probability of not being satisfied can be found in Cluster 4 (price-sensitive consumers), whereas assortment-oriented consumers have the highest probability of being completely satisfied.

According to research findings, latent class analysis fulfilled its purpose. Five clusters that differ in socio-demographic and behavioural characteristics have been identified, named and explained, suggesting that hypothesis $(\mathrm{H} 1)$ has been confirmed. In general, it can be concluded that price-sensitive consumers show the highest level of dissatisfaction, disinterested consumers are not satisfied, grey consumers are indifferent, convenience-oriented consumers are satisfied while assortment-oriented consumers are the most satisfied with all the observed factors.

\section{CONCLUSION}

As already stated, food retail sector lacks studies fusing satisfaction with retail store elements and customer segmentation. Therefore, this study contributes to the existing literature on market segmentation by providing a deeper understanding of different consumer segments based on their level of satisfaction with retail store attributes. In that context, five consumer segments were identified: convenience-oriented, disinterested, assortment-oriented, price-sensitive and grey consumers. Each segment is described in terms of socio-demographic and behavioural variables, providing useful insights into different consumer profiles in the Croatian food retailing.
Outcomes can be beneficial to both marketers and retailers to adopt the proper approach and develop appropriate retail and marketing strategies to target particular consumer segment. In addition, our findings could be helpful for further studies addressing this issue, particularly in the environment of the Croatian retail sector. So far, no identified study has merged consumer segmentation with the latent class analysis for the Croatian retail market.

Our findings indicate the importance of developing and implementing retail and marketing strategies that focus on five segments of customers with different characteristics. Based on the findings reported in the previous section, practical directions and managerial implications for each customer segment are proposed and discussed. Similarly to consumers in Clusters 3 and 4, consumers in Cluster 1 are least satisfied with prices. In that sense, retailers could enhance satisfaction of these segments by offering promotional markdowns, coupons, price bundling and multiple-unit pricing. Additionally, reward programmes as a form of customer management should be considered. Thus, launching, promoting and offering frequent-shopper or loyalty programmes may result in encouraging repeated purchase behaviour, as well as maintaining and increasing their satisfaction and loyalty. Importantly, loyalty programmes should distinguish a retailer from its competitors and emphasise well-designed benefits for customers. Furthermore, loyalty programmes are a valuable source of demographics, past purchases, frequency and favourite products, and marketers should use this information when creating marketing campaigns and adverts to target customers effectively.

The second largest cluster (Cluster 2) consisting of disinterested consumers is worth further consideration. When examining their assortment, retailers may consider introducing innovative store-branded products to enhance and expand assortment, especially in categories where there is no market-leading national brand. This could be achieved by pursuing a multiple-tier 
store brand strategy, e.g. by creating multiple price tiers. Many store brands today adopt different price/quality options, thus offering lowcost, value and premium ones (Grewal, 2018). Consequently, extended assortment and the introduction of novel products could provide an exciting and stimulating shopping experience for these consumers, thus capturing their attention and turning them into curious consumers.

As noted previously, both assortment-oriented consumers in Cluster 3 and price-sensitive consumers in Cluster 4 exhibit low levels of satisfaction with prices. By using different promotion instruments, price-sensitive consumers would be particularly encouraged to take advantage of lower prices. In the context of assortment-oriented and price-sensitive consumers, both price promotion (temporary price reductions, multiitem promotions, coupons, etc.) and non-price promotion tools (displays, promotion events, etc.) can be utilised. For this purpose, weekly flyers including recent promotions and various discounts on a wide range of products can be used. In particular, offering frequent-shopper programme could be appealing to price-sensitive consumers. Additionally, a stronger emphasis should be put on store label goods and retailers should use promotion events to support their store brands.

As regards Cluster 5, approaching this ageing segment properly is crucial in meeting their needs and improving their overall shopping experience and satisfaction. In that context, a positive in-store experience and human interaction should be provided to establish and build a trusting relationship with older customers. Consequently, the role of in-store staff through shopping assistance, personal engagement and information sharing should be emphasised. In addition, retailers could consider providing discounts, exclusive coupons or gifts for special occasions (e.g. birthdays, etc.) for these consumers to make them feel valued and special.

There are several limitations that should be considered when interpreting the findings. Given that convenience sampling used, the results have to be considered with attention. In addition, since the research was carried out in a single Croatian county, the results should be interpreted keeping in mind that sample representativeness was limited. Another limitation refers to applying factor scores as an alternative of the initial list of items in segmentation analysis. Finally, the current study was limited by its research period duration. To satisfy the needs of any future research, a larger sample size covering a wider geographic area is required. Additionally, the research should be conducted over a longer period of time and focus on respondents' selection. Also, an all-inclusive list of items should be included instead of aggregated factor scores to identify additional target classes and more differences.

\section{References}

1. Anderson, E. W., Fornell, C., \& Lehmann, D. R. (1994). Customer satisfaction, marketshare, and profitability: findings from Sweden. Journal of Marketing, 58(3), 53-66.

2. Anić, I.-D., Rajh, E., \& Piri Rajh, S. (2015). Exploring consumers' food-related decision-making style groups and their shopping behaviour. Economic Research, 28(1), 63-74.

3. Anselmsson, J. (2006). Sources of customer satisfaction with shopping malls: a comparative study of different customer segments. International Review of Retail Distribution and Consumer Research, 16(1), 115-138.

4. Bloom, D. E., \& Luca, D. L. (2016). The Global Demography of Aging: Facts, Explanations, Future. In J. Piggott \& A. Woodland (Eds.), Handbook of the Economics of Population Aging, (pp. 3-56.). Amsterdam: Elsevier Science 
5. Bourlakis, M. A., Ness, M. R., \& Vasilios Priporas, C. (2006). The Greek food shopper: Segmentation on the basis of attitudes to store features. EuroMed Journal of Business, 1(2), 29-49.

6. Burns, D., \& Neisner, L. (2006). Customer satisfaction in a retail setting: The contribution of emotion. International Journal of Retail \& Distribution Management, 34(1), 49-66.

7. Bustamante, J., \& Rubio, N. (2017). Measuring customer experience in physical retail environments. Journal of Service Management, 28(5), 884-913.

8. Calvert, P. (2006). Improving the Quality of Library Services for Students with Disabilities. Westport: Libraries Unlimited.

9. Calvo-Porral, C., \& Levy-Mangin, J.-P. (2017). Specialty food retailing: examining the role of products' perceived quality. British Food Journal, 119(7), 1511-1524.

10. Carpenter, J. M., \& Moore, M. (2006). Consumer demographics, store attributes, and retail format choice in the US grocery market. International Journal of Retail \& Distribution Management, 34(6), 434-452.

11. Dass, M., \& Kumar, P. (2012). Assessing category vulnerability across retail product assortments. International Journal of Retail \& Distribution Management, 40(1), 64-81.

12. Francioni, B., Savelli, E., \& Cioppi, M. (2018). Store satisfaction and store loyalty: The moderating role of store atmosphere. Journal of Retailing and Consumer Services, 43, 333-341.

13. Ganesh, J., Reynolds, K. E., \& Luckett, M. G. (2007). Retail patronage behaviour and shopper typologies: a replication and extension using a multi-format, multi-method approach. Journal of the Academy of Marketing Science, 35(3), 369-381.

14. Garrido-Morgado, A., González-Benito, O., \& Martos-Partal, M. (2016). Managing In-Store Stimuli for Different Private Label Tiers. In M. Gomez-Suarez \& M. P. Martinez-Ruiz (Eds.), Handbook of Research on Strategic Retailing of Private Label Products in a Recovering Economy (pp. 225-243.). Hershey: Business Science Reference.

15. Green, P. E., Carmone, F. J., \& Wachspress, D. P. (1976). Consumer segmentation via latent class analysis. Journal of Consumer Research, 3, 170-174.

16. Grewal, D. (2018). Retail Marketing Management: The 5 Es of Retailing. SAGE Publications Ltd.

17. Grewal, D., Berry, L. L., \& Seiders, K. (2002). Understanding service convenience. Journal of Marketing, 66(3), 1-17.

18. Gupta, S., \& Randhawa, G. (2008). Retail Management. Atlantic Publishers \& Dist., Delhi, India.

19. Hair, J. F., Black, W. C., Balin, B. J., \& Anderson, R. E. (2010). Multivariate data analysis. New York, NY: Maxwell Macmillan International Editions.

20. Ham, M. (2009). Consumer segmentation based on the level of environmental responsibility. Market, 21(2), 183-202.

21. Hamka, F., Bouwman, H., de Reuver, M., \& Kroesen, M. (2014). Mobile customer segmentation based on smartphone measurement. Telematics and Informatics, 31(2), 220-227.

22. Hare, C., Kirk, D., \& Lang, T. (2001). The food shopping experience of older consumers in Scotland: critical incidents. International Journal of Retail \& Distribution Management, 29(1), 25-40.

23. Hill, N., Brierley, J., \& MacDougall, R. (2003). How to Measure Customer Satisfaction. Hampshire: Gower Publishing Ltd.

24. Hill, N., \& Alexander, J. (2006). The Handbook of Customer Satisfaction and Loyalty Measurement. Hampshire: Gower Publishing Ltd.

25. Hill, N., Roche, G., \& Allen, R. (2007). Customer Satisfaction: The Customer Experience Through the Customer's Eyes. London: Cogent Publishing Ltd.

26. Huddleston, P., Whipple, J., Nye Mattick, R., \& Jung Lee, S. (2009). Customer satisfaction in food retailing: comparing specialty and conventional grocery stores. International Journal of Retail \& Distribution Management, 37(1), 63-80. 
27. Irfan, W., Siddiqui, D., \& Ahmed, W. (2019). Creating and retaining customers: perspective from Pakistani small and medium retail stores. International Journal of Retail \& Distribution Management, 47(4), 350-367.

28. Juhl, H. J., Kristensen, K., \& Ostergaard, P. (2002). Customer satisfaction in European food retailing. Journal of Retailing and Consumer Services, 9(6), 327-334.

29. Kesić, T., \& Piri-Rajh, S. (2003.). Market segmentation on the basis of foodrelated lifestyles of Croatian families. British Food Journal, 105(3), 162-174.

30. Kesić, T., Piri Rajh, S., \& Kesić, H. (2008). Market segmentation in the Republic of Croatia according to food-related lifestyle, Economic Review, 59(9-10), 503-522.

31. Kesić, T., \& Piri Rajh, S. (2009). Longitudinal study of food-related lifestyle of Croatian consumers. Market, 21(2), 149-166.

32. Kotler, P., \& Armstrong, G. (2010). Principles of Marketing. Upper Saddle River, NJ: Pearson Education Inc.

33. Kotler, P., \& Keller, K. L. (2015). Marketing management, Global edition. Harlow: Pearson Education.

34. Kotler, P., Armstrong, G., Harris, L. C., \& Piercy, N. (2017). Principles of Marketing. Harlow: Pearson Education Limited.

35. Kovačić, D., Radman, M., \& Haas, R. (2002). Segmentation of city market customers in Croatia towards a marketing strategy for fruit and vegetable markets. Die Bodenkultur, 53(4), 207-216.

36. Kumar, N., \& Steenkamp, J.-B. E. M. (2007). Private label strategy: How to meet the store brand challenge. Boston, MA: Harvard Business School Press.

37. Kumar, V., Dalla Pozza, I., \& Ganesh, J. (2013). Revisiting the satisfaction-loyalty relationship: empirical generalizations and directions for future research. Journal of Retailing, 89(3), 246-262.

38. Lamb, C., Hair, J., \& McDaniel, C. (2011). Marketing. Mason, OH: South-Western Cengage Learning.

39. Lauterborn, B. (1990). New Marketing Litany: Four P's Passe: C-Words Take Over. Advertising Age, 61(41), 26.

40. Lazarsfeld, P. F. (1950). The logical and mathematical foundation of latent structure analysis. In: S. A. Stouffer et al. (Eds.), Measurement and Prediction (pp. 362-412). Princeton, NJ: Princeton University Press.

41. Levy, M., Weitz, B. A., \& Grewal, D. (2012). Retailing Management. New York, NY: McGraw-Hill Education.

42. Martinelli, E., \& Balboni, B. (2012). Retail service quality as a key activator of grocery store loyalty. The Service Industries Journal, 32(14), 2233-2247.

43. Martinez-Ruiz, M. P., Jimenez-Zarco, A. I., \& Izquierdo-Yusta, A. (2010). Customer satisfaction's key factors in Spanish grocery stores: Evidence from hypermarkets and supermarkets. Journal of Retailing and Consumer Services, 17(4), 278-285.

44. McDonald, M., \& Dunbar, I. (2012). Market Segmentation: How to Do It and How to Profit from It. West Sussex: John Wiley \& Sons.

45. McDougall, G., \& Levesque, T. (2000). Customer satisfaction and future intentions: the role of perceived value and service quality. Journal of Services Marketing, 14(5), 392-410.

46. Meneely, L., Strugnell, C., \& Burns, A. (2009). Elderly consumers and their food store experiences. Journal of Retailing and Consumer Services, 16(6), 458-465.

47. Mihić, M. (2002.). Segmentation of the Croatian Supermarket Shoppers on the Basis of the Affective and Cognitive Variables. In M. Čičić \& N. Brkić (Eds.), Proceedings of International Conference of the Faculty of Economics Sarajevo - ICES 2002 Transition in Central and Eastern Europe - Challenges of 21st Century (pp. 443-449.). Sarajevo: University of Sarajevo, Faculty of Economics.

48. Mihić, M. (2006). Segmentation of supermarket shoppers based on their satisfaction with sales staff and store design: Multivariance analysis. Economic review, 57(12), 919-938. 
49. Mihić, M., \& Kursan, I. (2010). Market Segmentation Based on the Consumers' Impulsive Buying Behaviour. Econviews, 23(2), 385-399.

50. Mittal, V., \& Kamakura, W. A. (2001). Satisfaction, repurchase intent, and repurchase behavior: investigating the moderating effect of customer characteristics. Journal of Marketing Research, 38(1), 131-142.

51. Morschett, D., Swoboda, B., \& Foscht, T. (2005). Perception of store attributes and overall attitude towards grocery retailers: the role of shopping motives. International Review of Retail, Distribution and Consumer Research, 15(4), 423-447.

52. Ness, M., Gorton, M., \& Kuznesof, S. (2002). The student food shopper: Segmentation on the basis of attitudes to store features and shopping behaviour. British Food Journal, 104(7), 506-525.

53. Nylund, K., Muthen, B., \& Asparouhov, T. (2007). Deciding on the Number of Classes in Latent Class Analysis: A Monte Carlo Simulation Study. Structural Equation Modelling: An Interdisiplinary Journal, 14(4), 533-569.

54. Oliver, R. L. (1980). A cognitive model of the antecedents and consequences of satisfaction decisions. Journal of Marketing Research, 17(4), 460-469.

55. Oliver, R. L. (2014). Satisfaction: A Behavioral Perspective on the Consumer. London: Routledge.

56. Ong, F. S. J., Kitchen, P., \& Jama, A. T. (2008). Consumption patterns and silver marketing: an analysis of older consumers in Malaysia. Marketing Intelligence \& Planning, 26(7), 682-698.

57. Pan, Y., \& Zinkhan, G. (2006). Determinants of retail patronage: a meta-analytical perspective. Journal of Retailing, 82(3), 229-243.

58. Parment, A. (2013). Generation Y vs. Baby Boomers: Shopping behavior, buyer involvement and implications for retailing. Journal of Retailing and Consumer Services, 20(2), 189-199.

59. Peker, S., Kocyigit, A., \& Eren, P. E. (2017). LRFMP model for customer segmentation in the grocery retail industry: a case study. Marketing Intelligence \& Planning, 35(4), 544-559.

60. Peterson, R. A. (1994). A Meta-Analysis of Cronbach's Coefficient Alpha. Journal of Consumer Research, 21(2), 381-391.

61. Ramírez-Hurtado, J. M., \& Berbel-Pineda, J. M. (2014). Identification of Segments for Overseas Tourists Playing Golf in Spain: A Latent Class Approach. Journal of Hospitality Marketing \& Management, 24(6), 652-680.

62. Seiders, K., Voss, G. B., Grewal, D., \& Godfrey, A. L. (2005). Do satisfied customers buy more? Examining moderating influences in a retailing context. Journal of Marketing, 69(4), 26-43.

63. Sell, A., Mezei, J., \& Walden, P. (2014). An attitude-based latent class segmentation analysis of mobile phone users. Telematics and Informatics, 31(2), 209-219.

64. Sharma, P. K. (2019). Thinking salesman: Advance strategies to achieve breakthrough in personal and sales success. Notion Press, India

65. Sivadas, E., \& Baker\&Prewitt, J. (2000). An examination of the relationship between service quality, customer satisfaction, and store loyalty. International Journal of Retail \& Distribution Management, 28(2), 73-82.

66. Sivakumar, A. (2007). Retail Marketing. New Delhi: Excel Books.

67. Smith, W. R. (1956). Product differentiation and market segmentation as alternative marketing strategies. Journal of Marketing, 21(1), 3-8.

68. Sunder, V. K. (2011). Outsourcing and Customer Satisfaction: A Study of PC Help-Desk Services. USA: Xlibris corporation.

69. Theodoridis, P. K., \& Chatzipanagiotou, K. C. (2009). Store image attributes and customer satisfaction across different customer profiles within the supermarket sector in Greece. European Journal of Marketing, 43(5/6), 708-734. 
70. Vermunt, J. K., \& Magdison, J. (2005). Technical Guide for Latent GOLD Choice 4.0. Basic and Advanced. Belmont, MA: Statistical Innovations Inc.

71. Willems, K., Brengman, M., \& van de Sanden, S. (2017). In-store proximity marketing: experimenting with digital point-of-sales communication. International Journal of Retail \& Distribution Management, 45(7/8), 910-927. 